\title{
COMPARISON OF ETHANOL AND ACETALDEHYDE TOXICITY IN RAT ASTROCYTES IN PRIMARY CULTURE
}

\author{
Lucija ŠARC ${ }^{1}$ and Metoda LIPNIK-ŠTANGELJ ${ }^{2,3}$ \\ University Medical Centre, Poison Control Centre ${ }^{1}$, University of Ljubljana, Faculty of Medicine², Ljubljana, \\ University of Maribor, Faculty of Medicine ${ }^{3}$, Maribor, Slovenia \\ Received in November 2008 \\ Accepted in April 2009
}

\begin{abstract}
This study compared the effects of toxicity of ethanol and its first metabolite acetaldehyde in rat astrocytes through cell viability and cell proliferation. The cells were treated with different concentrations of ethanol in the presence or absence of a catalase inhibitor 2-amino-1,2,4 triazole (AMT) or with different concentrations of acetaldehyde. Cell viability was assessed using the trypan blue test. Cell proliferation was assessed after 24 hours and after seven days of exposure to either ethanol or acetaldehyde.

We showed that both ethanol and acetaldehyde decreased cell viability in a dose-dependent manner. In proliferation studies, after seven days of exposure to either ethanol or acetaldehyde, we observed a significant dose-dependent decrease in cell number. The protein content study showed biphasic dose-response curves, after 24 hours and seven days of exposure to either ethanol or acetaldehyde. Co-incubation in the presence of AMT significantly reduced the inhibitory effect of ethanol on cell proliferation.

We concluded that long-term exposure of astrocytes to ethanol is more toxic than acute exposure. Acetaldehyde is a much more potent toxin than ethanol, and at least a part of ethanol toxicity is due to ethanol's first metabolite acetaldehyde.
\end{abstract}

KEY WORDS: 2-amino-1,2,4 triazole, AMT, cell proliferation, cell viability, trypan blue

Ethanol consumption has long been associated with brain damage. Numerous experimental studies and necropsy examinations of chronic alcoholics have shown a wide range of structural and functional alterations in neurons and astrocytes (1-3). Such alterations are also seen in children with the foetal alcohol syndrome (4). Astrocytes are the major brain cell population; they play an important role in guiding migrating neurons during development, in regulating neurotransmitter and ion levels, in neuron nutrition, and in production of neurotrophic factors (5). Astrocytes are also a major site for bioactivation and detoxification of neurotoxins (6). Many studies have shown that both ethanol and acetaldehyde disturb astroglial growth and differentiation; however, the mechanism remained elusive (7-11). In addition, a number of ethanol effects, including psychopharmacological and neurotoxic effects, are believed to be mediated through its first metabolite, acetaldehyde (12-14).

Acetaldehyde, derived from peripheral metabolism of ethanol, crosses the blood-brain barrier with difficulty due to alcohol- and aldehyde-dehydrogenase (15). The localisation and relevance of ethanol metabolism in the brain is still controversial. The adult mammalian brain contains three enzyme systems for oxidising ethanol to acetaldehyde: cytochrome P450 (CYP) 2E1, catalase, and alcohol-dehydrogenase (16). Studies of naive rat brain have established a crucial role of catalase in oxidising ethanol and forming acetaldehyde. In addition, no evidence of alcohol dehydrogenase or CYP2E1 in this process was found. Metyrapone (CYP inhibitor) or pyrazole 
(alcohol-dehydrogenase inhibitor) did not affect the formation of acetaldehyde from ethanol in rat brain homogenates; at the same time, the presence of catalase inhibitors 2-amino-1,2,4 triazole (AMT), cyanamide, or sodium azide lowered acetaldehyde formation in a dose-dependent manner (17-20). The enzyme activity is localised exclusively in the microperoxisomes of aminergic neurone perikaryons and in glial cells (21). Many pieces of data support the notion that acetaldehyde is endowed with positive reinforcing properties, which play a crucial role in mediating ethanol euphoria and pave the way for alcohol craving (22). Animals pre-treated with catalase inhibitor AMT showed shorter ethanol narcosis period and lower mortality (23), less locomotor depression (24), blockade of ethanol-induced taste aversion and reduction of ethanol intake (25). The brain catalase system seems to play a role in the development of tolerance to the hypnotic effect of ethanol, but it does not alter tolerance to the hypothermic or metabolic effects (26).

There is evidence that astrocytes may respond to different injuries by altering phenotype, which involves upregulation of a large number of molecules (27). It was reported that astrocytes in primary cultures respond to a range of neurotoxic compounds with a biphasic dose-response; response increases at low, subtoxic doses, and is followed by a decrease at higher, cytotoxic doses (28).

Literature reports separate data for ethanol and acetaldehyde effects on astrocyte viability and proliferation, obtained with different methods. There are no data if ethanol or acetaldehyde provoke biphasic response in primary astrocyte cultures.

The aim of this study was to compare the effect of ethanol and acetaldehyde toxicity on rat cortical astrocytes in primary culture by determining cell viability and cell proliferation. Our secondary goal was to establish the role of acetaldehyde in ethanol toxicity in cultured astrocytes.

\section{MATERIALS AND METHODS}

\section{Materials}

L-15 Leibowitz medium, foetal bovine serum (FBS), Dulbecco's modified Eagle medium and Ham's nutrient mixture F-12) (DMEM / F12), penicillinstreptomycin $\left(10,000 \mathrm{IU} \mathrm{mL}^{-1}-10,000 \mathrm{UG} \mathrm{mL}^{-1}\right)$
(P/S), and Dulbecco's phosphate buffered saline (PBS) were purchased from Gibco BRL, Life Technologies, Paisley, Scotland. Ethanol and acetaldehyde were from Merck, Darmstadt, Germany. AMT, staurosporine, trypan blue and bovine serum albumin (BSA) were obtained from Sigma Chemical Co., St. Louis, USA. Bio-Rad protein assay was obtained from Bio-Rad Laboratories, Munich, Germany.

\section{Animals}

Newborn Wistar rats (postnatal day 2) were obtained from our own breeding colony. The animals were maintained under constant environmental conditions, with an ambient temperature of $(22 \pm 1)^{\circ} \mathrm{C}$, relative humidity $(55 \pm 10) \%$, and a natural lightdark cycle. The breeding colony was kept in Ehret type 4 cages (Germany); the bedding material was Lignocel $3 / 4$. The colony received standard rodent diet (Altormin, Germany), and had free access to food and water. We used four newborn animals for each experiment.

All animal procedures were approved by the National Animal Ethical Committee of the Republic of Slovenia (licence number 323-02-232/2005/2) and were conducted in accordance with the European Convention for the protection of vertebrate animals used for experimental and other scientific purposes (ETS 123).

\section{Preparation of astrocyte cultures}

Primary cultures of rat cortical astrocytes were prepared from the brain of newborn Wistar rats. Newborn rats (postnatal day 2) were decapitated and the brains removed aseptically.

After removal of meninges, cortices were transferred to a Petri dish containing L-15 (Leibowitz) medium. The cortices were then mechanically dissociated into $10 \mathrm{~mL}$ of culture medium consisting of DMEM/F12 (1:1), $10 \% \mathrm{FBS}, 100 \mathrm{U} \mathrm{mL}^{-1}$ penicillin, and $100 \mu \mathrm{g} \mathrm{mL}^{-1}$ streptomycin. Cell suspension was triturated and plated onto $35 \mathrm{mmol} \mathrm{L}^{-1}\left(2 \times 10^{6}\right.$ cells per dish). Cells were grown at $37^{\circ} \mathrm{C}$ in a watersaturated air environment containing $10 \% \mathrm{CO}_{2}$ until they became confluent (10 to 12 days). Culture medium was changed every 48 hours after plating. The cultures were used for treatment with either ethanol or acetaldehyde.

The purity of our culture was checked using immunocytochemical staining for glial fibrillary acidic protein, which is the major component of astrocyte 
cytoskeleton. The staining indicated that more than $90 \%$ of the cells in our experimental model were astrocytes, which repeats our previous purity results (29).

\section{Treatment of the cells}

To determine toxic effects of ethanol and acetaldehyde after 24 hours of exposure, the cells were treated as follows: after the cultures became confluent, culture medium was replaced with $1 \mathrm{~mL}$ of fresh serum-free medium and the cells were treated with different concentrations of either ethanol $\left(50 \mathrm{mmol} \mathrm{L}^{-1}\right.$ to $\left.1200 \mathrm{mmol} \mathrm{L}^{-1}\right)$ or acetaldehyde $\left(0.25 \mathrm{mmol} \mathrm{L}^{-1}\right.$ to $150 \mathrm{mmol} \mathrm{L}^{-1}$ ), for 24 hours. In another set of experiments, the cells were pre-treated with catalase inhibitor AMT $\left(10 \mathrm{mmol} \mathrm{L}^{-1}\right)$ for six hours, and then treated with different concentrations of ethanol ( $50 \mathrm{mmol} \mathrm{L}^{-1}$ to $1200 \mathrm{mmol} \mathrm{L}^{-1}$ ) for 24 hours.

Ethanol and acetaldehyde effects after seven days of exposure were determined as follows: after the first medium changing ( $3^{\text {rd }}$ day after plating) the cells were grown in a medium containing different concentrations of either ethanol $\left(50 \mathrm{mmol} \mathrm{L}^{-1}\right.$ to $\left.1200 \mathrm{mmol} \mathrm{L}^{-1}\right)$ in the presence or absence of AMT $\left(10 \mathrm{mmol} \mathrm{L}^{-1}\right)$ or acetaldehyde $\left(0.25 \mathrm{mmol} \mathrm{L}^{-1}\right.$ to $150 \mathrm{mmol} \mathrm{L}^{-1}$ ) for the next seven days. The medium was changed every 48 hours.

Control cells were grown under the same conditions, but in the absence of ethanol or acetaldehyde, or were treated with $10 \mathrm{mmol} \mathrm{L}^{-1}$ AMT only.

After the treatment, cells from separate dishes were used for viability test, cell counting, or protein determination.

\section{Determination of cell viability}

Cell viability was assessed using the trypan blue test according to a modified method of Uliasz and Hewett (30) after having treated the cells with different concentrations of either ethanol or acetaldehyde for 24 hours. Positive control cells were treated with $1 \mu \mathrm{mol} \mathrm{L}-1$ staurosporine.

After the treatment, the culture medium was replaced by $0.1 \mathrm{~mL}$ of $0.4 \%$ trypan blue; after 1 minute of staining, the cultures were rinsed with PBS (pH 7.2). Cells excluding the stain were considered viable. The number of trypan blue-stained cells and trypan blue-free cells was counted using a light microscope at $100 \mathrm{x}$ magnification. The total number of cells scored per experimental point was 100 .

\section{Determination of cell proliferation}

Cell proliferation was assessed by cell counting and protein determination after treatment with different concentrations of either ethanol or acetaldehyde for 24 hours or seven days.

Cells were counted after treatment and removal of culture medium using a light microscope at $100 \mathrm{x}$ magnification (31). The total number of cells scored per experimental point was 100 .

Proteins were also determined after treatment and removal of culture medium, in cells harvested from individual dishes, according to the method of Bradford (32) using bovine serum albumin as a standard.

\section{Statistical analysis}

The results are shown as mean \pm standard error of mean (SEM) of three independent determinations. One-way ANOVA with Tukey's post hoc test were employed to calculate the significance of differences between the means. A p-value of $<0.05$ was considered statistically significant.

\section{RESULTS}

\section{The effect of ethanol and acetaldehyde on cell viability}

Incubation of the cultured astrocytes in the presence of ethanol for 24 hours did not influence cell viability until ethanol reached concentration of $700 \mathrm{mmol} \mathrm{L}^{-1}$. Estimated $\mathrm{EC}_{50}$ was $847.9 \mathrm{mmol} \mathrm{L}^{-1}$. Pre-treatment with AMT did not diminish the toxic effect of ethanol (Figure 1A). Acetaldehyde showed much higher toxicity than ethanol; cell viability was affected at $25 \mathrm{mmol} \mathrm{L}^{-1}$ of acetaldehyde, with $\mathrm{EC}_{50}$ of $47.2 \mathrm{mmol} \mathrm{L}^{-1}$ (Figure 1B).

\section{The effect of ethanol and acetaldehyde on cell proliferation}

Below the concentration $700 \mathrm{mmol} \mathrm{L}^{-1}$, acute exposure of the cultured astrocytes to ethanol for 24 hours did not affect the number of cells in the culture, either in the presence or absence of AMT (Figure 2A). Similarly, we did not observe any decrease in cell number after acute exposure to acetaldehyde until the cut-off concentration of $50 \mathrm{mmol} \mathrm{L}^{-1}$ (Figure 2B). Protein content showed biphasic effect of ethanol (Figure 2C) and acetaldehyde (Figure 2D) after 24 hours of exposure. Low concentrations stimulated 

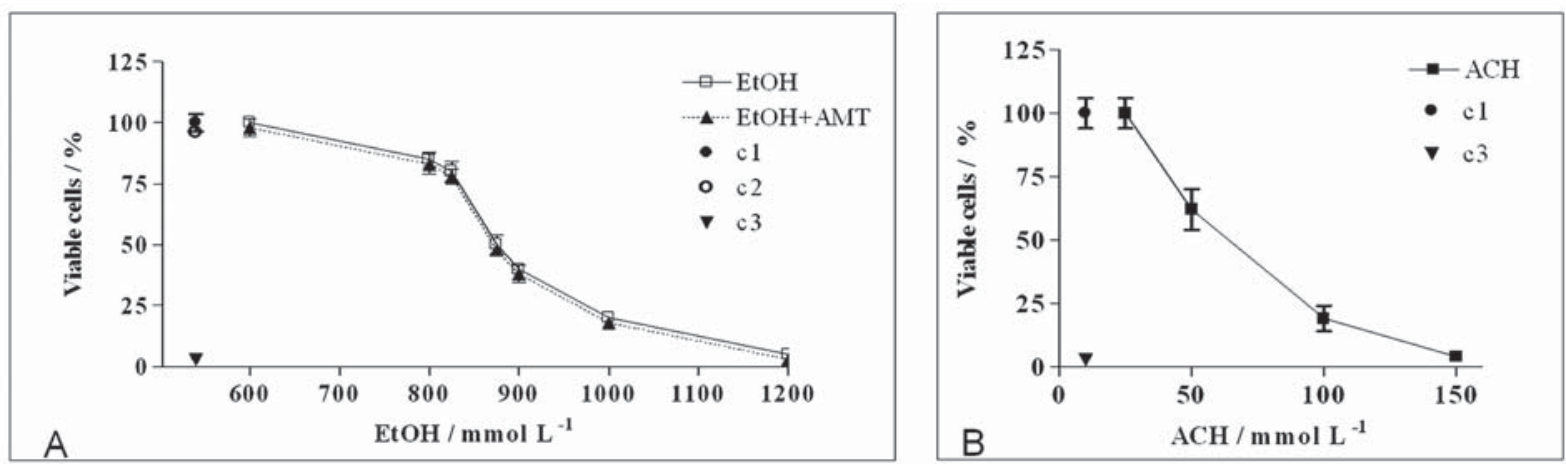

Figure 1 Effect of ethanol (EtOH) at different concentrations in the presence or absence of catalase inhibitor AMT (10 mmol $\left.\mathrm{L}^{-1}\right)$ $(A)$ and acetaldehyde $(A C H)(B)$ on the viability of cultured astrocytes after 24 hours of exposure. Each point is the mean \pm SEM of three independent determinations. c1, control cells - growth medium; $c 2$, control cells, treated with

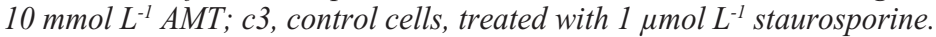

protein production, but it was inhibited at higher concentrations of either compound. Pre-incubation of the cells with AMT cancelled the biphasic effect of ethanol on protein production, and shifted the inhibitory effect to higher ethanol concentrations (Figure 2C).
Chronic exposure of growing cells to either ethanol or acetaldehyde significantly decreased cell number in the cultures. The first significant decrease in cell number versus control cells after seven days of exposure was observed at $200 \mathrm{mmol} \mathrm{L}^{-1}$ of ethanol, with an estimated $\mathrm{EC}_{50}$ of $240 \mathrm{mmol} \mathrm{L}^{-1}$.
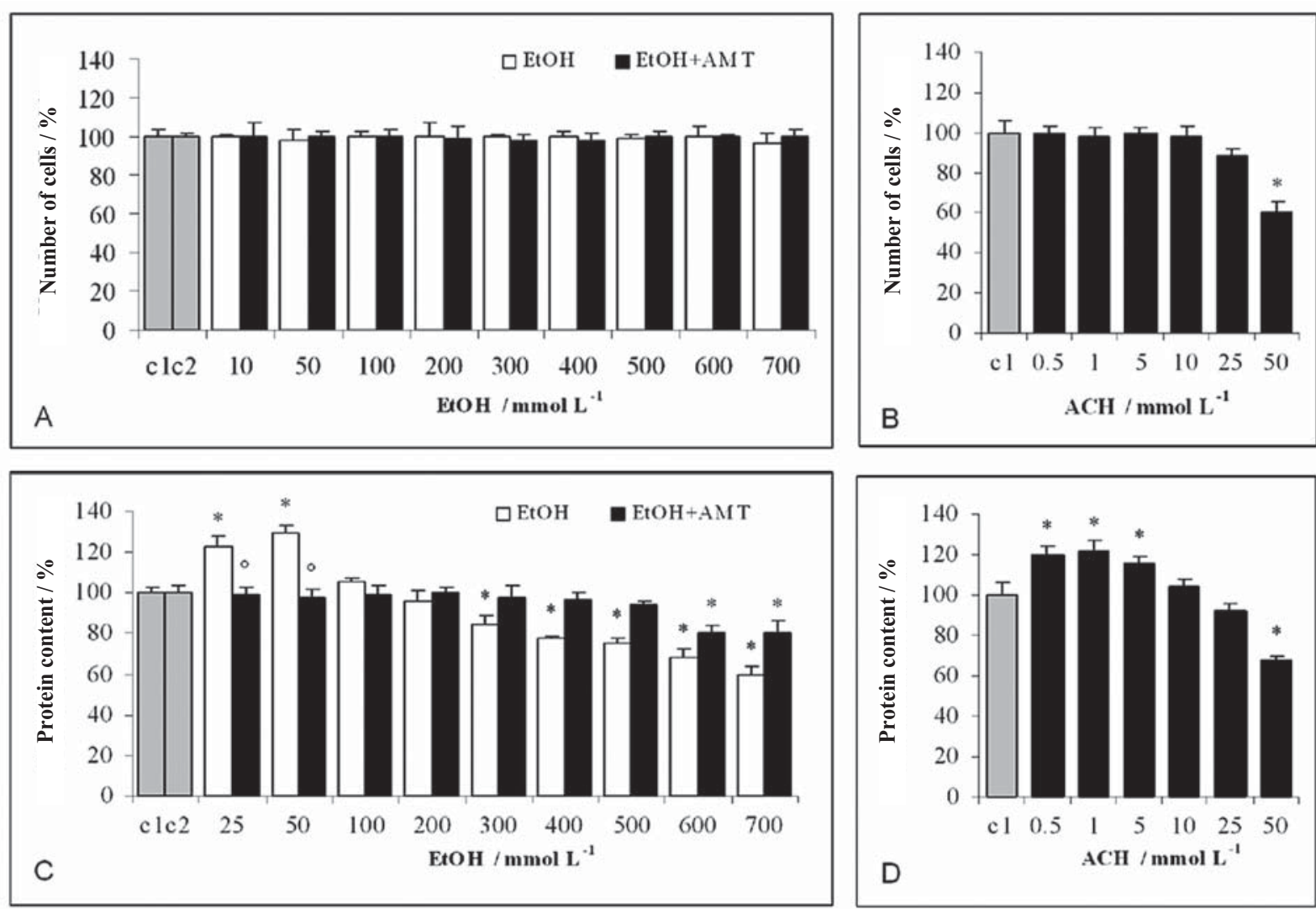

Figure 2 Effect of ethanol (EtOH) at different concentrations in the presence or absence of catalase inhibitor AMT (10 mmol $\left.L^{-1}\right)$ on cell count (A) and protein content (C) in cell culture, after 24 hours of incubation. Effect of acetaldehyde (ACH) at different concentrations on cell count (B) and protein content $(D)$ in cell culture, after 24 hours of incubation. Each bar is the mean $\pm S E M$ of three independent determinations. ${ }^{*} p<0.05$ versus control $c 1 ;{ }^{\circ} p<0.05$ versus values with the same ethanol concentration in the absence of AMT. c1, control cells-growth medium; 2 , control cells, treated with $10 \mathrm{mmol} \mathrm{L}^{-1}$ AMT. 
Pre-incubation with AMT reduced ethanol influence on proliferation by $24.1 \%$, with $\mathrm{EC}_{50}$ rising to $436.7 \mathrm{mmol} \mathrm{L}^{-1}$ (Figure 3C).

After seven days of exposure, acetaldehyde inhibited cell growth at much lower concentrations than ethanol; the first significant decrease in cell number was observed at $5 \mathrm{mmol} \mathrm{L}^{-1}$ acetaldehyde (Figure 3B). $\mathrm{EC}_{50}$ was $13 \mathrm{mmol} \mathrm{L}^{-1}$. Protein content first significantly dropped at $5 \mathrm{mmol} \mathrm{L}^{-1}$ acetaldehyde, with $\mathrm{EC}_{50} 8.7 \mathrm{mmol} \mathrm{L}^{-1}$ (Figure 3D).

\section{DISCUSSION}

Although brain damage associated with chronic consumption of ethanol is multifactorial and depends on a number of ethanol effects on the central nervous system, some data suggest that oxidative metabolism of ethanol and produced substances are involved in the aetiology of these effects (33). Many studies have shown that both ethanol and acetaldehyde disturb astroglial growth and differentiation; however, the mechanism has remained elusive $(8,11,34-39)$.

There are reports that ethanol at high concentrations intercalates into cell membranes, increasing membrane fluidity (40). In our study we have shown that ethanol at high concentrations ( $700 \mathrm{mmol} \mathrm{L}^{-1}$ and above) affects cell viability in primary rat cultures. This result is no surprise, because astrocytes are fairly resistant cell species with high antioxidant capacity. Compared to ethanol, acetaldehyde was much more potent; its first significant effect on cell viability was seen at a much lower concentration $\left(50 \mathrm{mmol} \mathrm{L}^{-1}\right)$.

Astrocytes are the most abundant brain cells. As such, they also provide metabolic and trophic support to neurones. Astrocytes are able to respond to an injury with altered phenotype. In such conditions they respond with increased production of intermediate filaments and structural glial fibrillary protein, with cell hypertrophy, and sometimes with cell proliferation
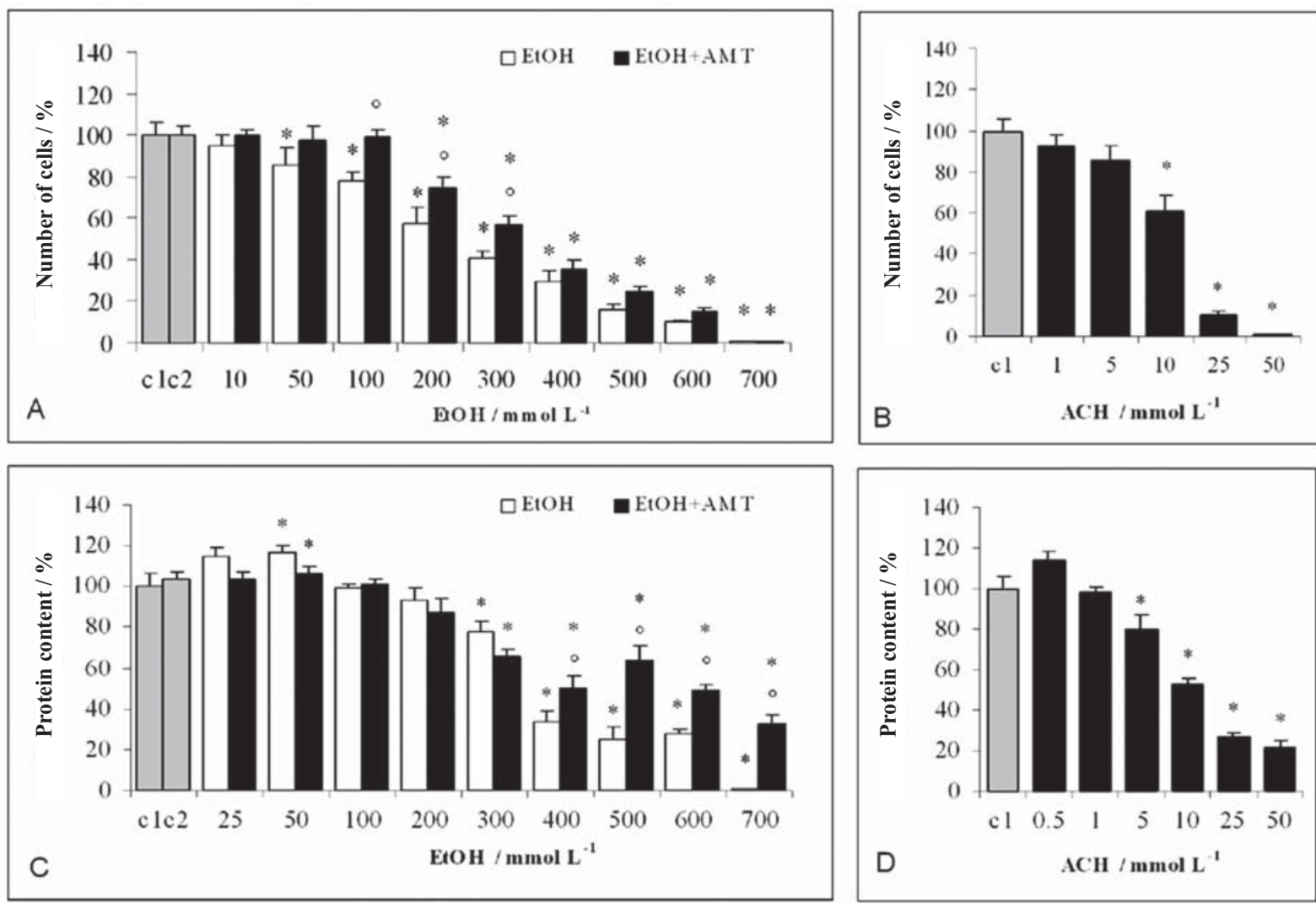

Figure 3 Effect of ethanol (EtOH) at different concentrations in the presence or absence of catalase inhibitor AMT on cell count $(A)$ and protein content $(C)$ in cell culture after seven days of incubation. Effect of acetaldehyde (ACH) at different concentrations on cell count $(B)$ and protein content $(D)$ in cell culture after seven days of incubation. Each bar is the mean \pm SEM of three independent determinations. ${ }^{*} p<0.05$ versus control $c 1 ;{ }^{\circ} p<0.05$ versus values with the same ethanol concentration in absence of AMT. c1, control cells - growth medium; 22 , control cells, treated with $10 \mathrm{mmol} \mathrm{L}^{-1} \mathrm{AMT}$. 
(41). This could explain the biphasic, hormetic dose-response effect, which we obtained in the cell proliferation test by measuring cell protein content.

We observed the biphasic effect of ethanol after 24 hours and after seven days of exposure; low concentrations of ethanol stimulated protein production, whereas higher concentrations inhibited it.

Astrocytes have a high antioxidant capacity. In oxidative stress, they react with upregulation of a large number of molecules including those controlling the protective system. Therefore, they can protect neurons against toxic damage (42). Watts et al. (43) showed the protective effect of co-cultured astrocytes on neurons, reducing the apoptosis rate after 12-hour and 24-hours exposure to $55 \mathrm{mmol} \mathrm{L}^{-1}$ and $88 \mathrm{mmol} \mathrm{L}^{-1}$ of ethanol. Neuron protection could be also speculated in our study at ethanol doses of $25 \mathrm{mmol} \mathrm{L}^{-1}$ and $50 \mathrm{mmol} \mathrm{L}^{-1}$, with significant increase in protein content after acute exposure. However, protein upregulation was blocked by pretreatment of astrocyte cultures with catalase inhibitor AMT, which decreased acetaldehyde production and, in turn, could have decreased the production of reactive oxygen species (ROS). Decreased ROS level production by neurons co-cultured with astrocytes during the second hour of exposure to $55 \mathrm{mmol} \mathrm{L}^{-1}$ and $88 \mathrm{mmol} \mathrm{L}^{-1}$ of ethanol was also found by Watts et al. (43).

Both ethanol and acetaldehyde inhibited astrocyte growth after seven days of exposure in a dosedependent manner, but acetaldehyde was much more toxic. Their inhibitory effect on proliferation was confirmed by low cell count and low protein content in cultures. The first significant decrease in cell count versus control was observed at $100 \mathrm{mmol} \mathrm{L}^{-1}$ of ethanol, and the first significant difference in protein content was seen at $300 \mathrm{mmol} \mathrm{L}^{-1}$. This difference could be related to the common astrocyte response to low doses of toxicants by altering the phenotype, which in turn leads to upregulation of a large number of molecules protecting the cell (28). According to basic toxicological data for acute oral toxicity in rats, acetaldehyde is 10 to 20 times a more potent toxin than alcohol (44). Our results for acetaldehyde go along these lines, as we observed the first significant decrease in cell count versus control at $5 \mathrm{mmol} \mathrm{L}^{-1}$.

The mechanism of action of ethanol on astroglial growth is still subject to debate. Proliferation of astrocytes is mainly controlled by soluble mitogenic factors such as growth factors acting on tyrosine kinase-coupled receptors $(45,46)$. Ethanol has been shown to inhibit basal astroglial proliferation and response to mitogenic factors such as IGF-1 and acetylcholine $(35,47)$. Ethanol (e.g., $30 \mathrm{mmol} \mathrm{L}^{-1}$ to $\left.250 \mathrm{mmol} \mathrm{L}^{-1}\right)$ inhibits cell proliferation $(34,48)$ and reduces incorporation of $\left[{ }^{3} \mathrm{H}\right]$ thymidine (49). High concentrations of ethanol alter cell-cycle kinetics of proliferating astrocytes by delaying the passage of the cells trough G1 (49). These effects appear to be dosedependent. At low concentrations (e.g., $14 \mathrm{mmol} \mathrm{L}^{-1}$ ) ethanol increases DNA, RNA, and protein synthesis (43). Ethanol also increases astrocyte death, both by necrosis and apoptosis (11).

A number of ethanol effects, including psychopharmacological and neurotoxic effects, are believed to be mediated by its first metabolite, acetaldehyde. However, there are only a few data about the cytotoxicity of acetaldehyde in astrocytes. Acetaldehyde, but not ethanol, increases intracellular calcium level, elevates transglutaminase activity, and causes significant DNA fragmentation and cell nuclei chromatin condensation in astrocytes $(50)$. We have shown that pretreatment with catalase inhibitor AMT significantly diminishes ethanol toxicity ( $28 \%$ lower after 24 hours of exposure and $24.1 \%$ lower after seven days of exposure). Our results are also in accordance with one of the rare reports about acetaldehyde production in cultured astrocytes, where $10 \mathrm{mmol} \mathrm{L}^{-1}$ AMT decreased acetaldehyde metabolism from ethanol by $52 \%$ (51).

To conclude, both ethanol and acetaldehyde show toxic effects on cultured astrocytes and both inhibit proliferation, which depends on the concentration and time of exposure. Long-term exposure of astrocytes to either ethanol or acetaldehyde is more toxic than acute exposure. Acetaldehyde is a much more potent toxin than ethanol. Moreover, at least a part of ethanol toxicity is due to its metabolising to acetaldehyde. Our study may contribute to better understanding of the involvement of ethanol and its oxidative metabolite acetaldehyde in the development of foetal alcohol syndrome due to ethanol exposure during pregnancy and in the development of morphological and functional changes in the CNS in chronic alcoholics.

\section{Acknowledgements}

This study was supported by the research grant P30067 by the Slovenian Research Agency, Republic of Slovenia. 


\section{REFERENCES}

1. Singh NP, Lai H, Khan A. Ethanol-induced single-strand DNA breaks in rat brain cells. Mutat Res1995;345:191-6.

2. Barret L, Soubeyran A, Usson Y, Eysseric H, Saxod R. Characterization of the morphological variations of astrocytes in culture following ethanol exposure. Neurotoxicology 1996;17:497-507.

3. Lamarche F, Gonthier B, Signorini N, Eysseric H, Barret L. Acute exposure of cultured neurones to ethanol results in reversible DNA single-strand breaks; whereas chronic exposure causes loss of cell viability. Alcohol Alcohol 2003;38:550-8.

4. Mattson SN, Schoenfeld AM, Riley EP. Teratogenic effects of alcohol on brain and behavior. Alcohol Res Health 2001;25(Suppl 3):185-91.

5. Kimelberg HK, Norenberg MD. Astocytes. Sci Am 1989;260:66-76.

6. Di Monte DA, Royland JE, Irwin I, Langston JW. Astrocytes as the site for bioactivation of neurotoxins. Neurotoxicology 1996;17:697-703.

7. Ledig M, Megias-Megias L, Tholey G. Maternal alcohol exposure before and during pregnancy: effect on development of neurons and glial cells in culture. Alcohol Alcohol 1991;26:169-76.

8. Ledig M, Tholey G, Megias-Megias L, Kopp P, Wedler F. Combined effects of ethanol and manganese on cultured neurons and glia. Neurochem Res 1991;16:591-6.

9. Holownia A, Ledig M, Copin JC, Tholey G. The effect of ethanol on HSP70 in cultured rat glial cells and in brain areas of rat pups exposed to ethanol in utero. Neurochem Res 1995;20:875-8.

10. Holownia A, Ledig M, Mapoles J, Ménez JF. Acetaldehydeinduced growth inhibition in cultured rat astroglial cells. Alcohol 1996;13:93-7.

11. Holownia A, Ledig M, Ménez JF. Ethanol-induced cell death in cultured rat astroglia. Neuro-Toxicol Teratol 1997;19:1416.

12. QuertemontE, Tambour S, Bernaerts P, Zimatkin SM, Tirelli E. Behavioral characterization of acetaldehyde in C57BL/6J mice: locomotor, hypnotic, anxiolytic and amnesic effects. Psychopharmacology (Berl) 2004;177:84-92.

13. Deitrich RA. Acetaldehyde: déjà vu du jour. J Stud Alcohol 2004;65:557-72.

14. Luke Y. Ethanol. In: Goldfrank LR, Flomenbaum NE, Lewin NA, Howland MA, Hoffman RS, Nelson LS, editors Goldfrank's Toxicologic Emergencies. $7^{\text {th }}$ ed. New York (NY): McGraw-Hill; 2002. p. 1147-61.

15. Zimatkin SM, Dietrich RA. Ethanol metabolism in the brain. Addict Biol 1997;2:387-413.

16. Hunt WA. Role of acetaldehyde in the actions of ethanol on the brain - a review. Alcohol 1996;13:147-51.

17. Aragon CM, Rogan F, Amit Z. Studies on ethanol-brain catalase interaction: evidence for central ethanol oxidation Alcoh Clin Exp Res 1991;15:165-9.

18. Gill K, Menez JF, Lucas D, Deitrich RA. Enzymatic production of acetaldehyde from ethanol in rat brain tissue. Alcohol Clin Exp Res 1992;16:910-5.

19. Aragon CM, Amit Z. Differences in ethanol-induced behaviors in normal and acatalasemic mice: systematic examination using a biobehavioral approach. Pharmacol Biochem Behav 1993;44:547-54.
20. Zimatkin SM, Buben AL. Ethanol oxidation in the living brain. Alcohol Alcohol 2007;42:529-32.

21. Zimatkin SM, Lindros KO. Distribution of catalase in rat brain: aminergic neurons as possible targets for ethanol effects. Alcohol Alcohol 1996;31:167-74.

22. Quertemont E, Eriksson CJ, Zimatkin SM, Pronko PS, Diana M, Pisano M, Rodd ZA, Bell RR, Ward RJ. Is ethanol a prodrug? Acetaldehyde contribution to brain ethanol effects. Alcohol Clin Exp Res 2005;29:1514-21.

23. Aragon CM, Spivak K, Amit Z. Effect of 3-amino1,2,4-triazole on ethanol-induced narcosis, lethality and hypothermia in rats. Pharmacol Biochem Behav 1991;39:559.

24. Aragon CM, Amit Z. The effect of 3-amino-1,2,4-triazole on voluntary ethanol consumption: evidence for brain catalase involvement in the mechanism of action. Neuropharmacology 1992;31:709-12.

25. Aragon CM, Spivak K, Amit Z. Blockade of ethanol induced conditioned taste aversion by 3 -amino-1,2,4-triazole: evidence for catalase mediated synthesis of acetaldehyde in rat brain. Life Sci 1985;37:2077-84.

26. Tampier L, Quintanilla ME. Effect of 3-amino-1,2,4-triazole on the hypothermic effect of ethanol and on ethanol tolerance development. Alcohol 1991;8:279-82.

27. Wilson JX. Antioxidant defense of the brain: a role for astrocytes. Can J Pharmacol 1997;75:1149-63.

28. Pentreath VW, Slamon ND. Astrocyte phenotype and prevention against oxidative damage in neurotoxicity. Hum Exp Toxicol 2000;19:641-9.

29. Lipnik-Stangelj M, Carman-Krzan M. Activation of histamine H1-receptor enhances neurotrophic factor secretion from cultured astrocytes. Inflamm Res 2004;53:245-52.

30. Uliasz TF, Hewett SJ. A microtiter trypan blue absorbance assay for the quantitative determination of excitotoxic neuronal injury in cell culture. J Neurosci Methods 2000;100:157-63

31. Protocol online. Your lab's reference book [displayed 21 April 2009]. Available at http://www.protocol-online.org/ prot/Image_Techniques/Microscopy/Light_Microscopy/ index.html

32. Bradford M. A rapid and sensitive method for quantitation of microgram quantities of protein utilizing the principle of protein-dye binding. Anal Biochem 1976;72:248-54.

33. Forn-Frías C, Sanchis-Segura C. The possible role of acetaldehyde in the brain damage caused by the chronic consumption of alcohol. Rev Neurol 2003;37:485-93.

34. Davies DL, Cox WE. Delayed growth and maturation of astrocytic cultures following exposure to ethanol: electron microscopic observations. Brain Res 1991;546:53-61.

35. Guizzeti M, Costa LG. Inhibition of muscarinic receptorstimulated glial cell proliferation by ethanol. J Neurochem 1996;67:2236-45.

36. Russo A, Palumbo M, Scifo C, Cardile V, Barcellona mL, Renis M. Ethanol-induced oxidative stress in rat astrocytes: role of hsp70. Cell Biol Toxicol 2001;17:153-68.

37. Muscoli C, Fresta M, Cardile V, Palumbo M, Renis M, Puglisi G, Paolino D, Nisticò S, Rotiroti D, Mollace V. Ethanol-induced injury in rat primary cortical astrocytes involves oxidative stress: effect of idebenone. Neurosci Lett 2002:329:21-4

38. Gonthier B, Signorini-Allibe N, Soubeyran A, Eysseric H, Lamarche F, Barret L. Ethanol can modify the effects of 
certain free radical-generating systems on astrocytes. Alcohol Clin Exp Res 2004;28:526-34.

39. Signorini-Allibe N, Gonthier B, Lamarche F, Eysseric H, Barret L. Chronic consumption of ethanol leads to substantial cell damage in cultured rat astrocytes in conditions promoting acetaldehyde accumulation. Alcohol Alcohol 2004;40:16371.

40. Rottenberg H. Membrane solubility of ethanol in chronic alcoholism. The effect of ethanol feeding and its withdrawal on the protection by alcohol of rat red blood cells from hypotonic hemolysis. Biochim Biophys Acta 1986;855:21122.

41. O'Callaghan JP, Jensen KF, Miller DB. Quantitative aspects of drug and toxicant induced astrogliosis. Neurochem Int 1995;26:115-24.

42. Wilson JX. Antioxidant defense of the brain: a role for astrocytes. Can J Physiol Pharmacol 1997;75:1149-63.

43. Watts LT, Rathinam ML, Schenker S, Henderson GI. Astrocytes protect neurons from ethanol-induced oxidative stress and apoptotic death. J Neurosci Res 2005;80:655-66.

44. Poisindex, [CD-ROM]. Greenwood Village, USA: Thompson Micromedex; 2008.

45. Labourdette G, Sensenbrenner M. Growth factors and their receptors in the central nervous system. In: Kettenmann H,
Ranson BR, editors. Neuroglia. New York (NY): Oxford University Press; 1995. p. 441-59.

46. Lauder JM. Neurotransmitters as growth regulatory signals: role of receptors and second messengers. Trends Neurosci 1993;16:233-40.

47. Resnicoff M, Rubini M, Baserga R, Rubin R. Ethanol inhibits insulin-like growth factor-1-mediated signalling and proliferation of $\mathrm{C} 6$ rat glioblastoma cells. Lab Invest 1994;71:657-62.

48. Luo J, Miller MW, Growth factor-mediated neural proliferation: target of ethanol toxicity. Brain Res Brain Res Rev 1998;27:157-67.

49. Guerri C, Sáez R, Sancho-Tello M, Martin de Aquilera E, Renau-Piqueras J. Ethanol alters astrocyte development: a study of critical periods using primary cultures. Neurochem Res 1990;15:559-65.

50. Holownia A, Ledig M, Braszko JJ, Ménez JF. Acetaldehyde cytotoxicity in cultured rat astrocytes. Brain Res 1999;833:2028.

51. Eysseric H, Gonthier B, Soubeyran A, Richard MJ, Daveloose D, Barret L. Effects of chronic ethanol exposure on acetaldehyde and free radical production by astrocytes in culture. Alcohol 2000;21:117-25. 


\section{Izvleček}

\section{PRIMERJAVA TOKSIČNOSTI ETANOLA IN ACETALDEHIDA ZA PODGANJE ASTROCITE V PRIMARNI KULTURI}

V študiji smo primerjali toksičnost etanola in njegovega prvega metabolita acetaldehida za podganje astrocite $\mathrm{z}$ določitvijo celične viabilnosti in proliferacije. Celične kulture smo tretirali z različnimi koncentracijami etanola, etanola $\mathrm{v}$ prisotnosti inhibitorja katalaze 2-amino-1,2,4 triazol-a (AMT) ali z različnimi koncentracijami acetaldehida. Celično viabilnost smo vrednotili s pomočjo testa s tripanskim modrilom, celično proliferacijo pa s štetjem celic in določitvijo koncentracije proteinov po 24-urni, kot tudi 7-dnevni izpostavljenosti.

S študijo smo pokazali, da tako etanol kot tudi acetaldehid $\mathrm{v}$ odvisnosti od njune koncentracije zmanjšata celično viabilnost. V študiji proliferacije sta etanol in acetaldehid, $v$ odvisnosti od njunih koncentracij, značilno zmanjšala število celic po 7-dnevni izpostavljenosti. Pri ugotavljanju vsebnosti proteinov smo dobili bifazno krivuljo tako po 24-urni, kot tudi po 7-dnevni izpostavljenosti različnim koncentracijam etanola oziroma acetaldehida. Prisotnost AMT je signifikantno zmanjšala učinek etanola na celično proliferacijo.

Zaključimo lahko, da je dolgotrajna izpostavljenost astrocitov etanolu bolj toksična kot akutna. Acetaldehid je močnejši toksin kot etanol in vsaj del toksičnosti etanola je posledica delovanja njegovega prvega metabolita, acetaldehida.

KLJUČNE BESEDE: AMT, proliferacija, tripansko modrilo, viabilnost

\section{CORRESPONDING AUTHOR:}

Metoda Lipnik-Štangelj

University of Ljubljana, Faculty of Medicine

Department of Pharmacology and Experimental Toxicology

Korytkova 2, SI-1000 Ljubljana, Slovenia

E-mail:metoda.lipnik-stangelj@mf.uni-lj.si 